\title{
Species composition, stand characteristics, aboveground biomass, and carbon stock of mangroves in Panabo Mangrove Park, Philippines
}

\author{
JEMER A. ALIMBON ${ }^{1, \varphi}$, MARK RONALD S. MANSEGUIAO ${ }^{2, v v}$ \\ ${ }^{1}$ Department of Teacher Education, UM Tagum College, Mabini St., Tagum City 8100, Davao del Norte, Philippines. \\ Tel.: +63-907-943-6788, "email: alimbon.jemer@gmail.com \\ ${ }^{2}$ Institute of Teacher Education, Davao del Norte State College Davao del Norte State College, New Visayas, Panabo City 8105, Davao del Norte, \\ Philippines." "email: markronald.manseguiao@dnsc.edu.ph
}

Manuscript received: 19 April 2021. Revision accepted: 10 May 2021

\begin{abstract}
Alimbon JA, Manseguiao MRS. 2021. Species composition, stand characteristics, aboveground biomass, and carbon stock of mangroves in Panabo Mangrove Park, Philippines. Biodiversitas 22: 3130-3137. Mangrove ecosystems have been recognized for their roles in climate change mitigation through their carbon sequestration capacity. However, information on the ecology and carbon stock of mangroves is limited. Thus, this study assessed the species composition, stand characteristics, aboveground biomass, and carbon stock of mangroves in Panabo Mangrove Park, Panabo City, Davao del Norte, Philippines. Data for vegetation analysis and biodiversity assessment were collected using transect line plots method. Meanwhile, aboveground biomass estimation was conducted using nondestructive method. Twenty plots with size of $10 \mathrm{~m} \times 10 \mathrm{~m}$ each were established to account for the stand characteristics and aboveground biomass of mangroves. Species composition data identified five species from four families. Avicennia marina was the most important species with an importance value of $153.33 \%$. Stand structure analysis revealed a basal area of $14.65 \mathrm{~m}^{2} \mathrm{ha}^{-1}$ and a mean density of 11835 stems ha ${ }^{-1}$. Biodiversity indices indicated very low species diversity $\left(H^{\prime}=1.027\right)$, low species richness $(R=0.5148)$ and less even distribution of species $(J=0.6383)$. Using allometric equation, the aboveground biomass was $77.45 \mathrm{Mg}^{-1}$ with an estimated stored carbon of $37.18 \mathrm{Mg} \mathrm{ha}^{-1}$ and sequestration potential of $136.44 \mathrm{Mg} \mathrm{CO}_{2} \mathrm{ha}^{-1}$. These baseline data demonstrate that the area can store and sequester potential amounts of carbon and carbon dioxide, respectively, despite the low diversity.
\end{abstract}

Keywords: Avicennia marina, biomass, carbon stock, diversity, Philippine mangroves

\section{INTRODUCTION}

Mangroves are community of trees, shrubs, trunkless palms, and ground fern that are morphologically adapted to tidal ecosystems (Duke 2011). The mangrove ecosystem is recognized for the goods and services it provides to other organisms and the biosphere in general (Alongi 2012). Hence, it is regarded as an "ecologically and economically important forest of the tropics" (Alongi 2014). It serves as a habitat and nursery ground for crabs, fishes, and shrimps and a buffer of coastal communities against typhoons and tsunami (Wagner et al. 2004; Melana et al. 2005; FAO 2007; Duke 2011; Camacho et al. 2020). It provides food and livelihood for nearby residents (Satyanarayana et al. 2012; Sawairnathan and Halimoon 2017; Gevaña et al. 2019) and plays as sink of carbon (Gevaña et al. 2019; Dinilhuda et al. 2020).

Worldwide, the number of mangrove species is still uncertain but ranges from 50 to 70 species (FAO 2007). The Philippines, a tropical archipelagic country in Southeast Asia which is considered as the most mangrove diverse region in the world (Spalding et al. 2010), has a mangrove area of 247,362 hectares [as of 2003] and has relatively high diversity with 35 true mangrove species making it rank fourth worldwide (FAO 2007). However, the extent of mangrove areas in the country has declined for the past century (Buitre et al. 2019) due to natural disturbances as well as anthropogenic activities (Garcia et al. 2014) such as overexploitation and conversion (Primavera 2004).

Numerous assessments on mangrove biodiversity in the Philippines were already done. However, only few studies in the country (e.g., Gevaña and Pampolina 2009; Camacho et al. 2011; Castillo and Breva 2012; Abino et al. 2014a, b; Barcelete et al. 2016; Bigsang et al. 2016; Venturillo 2016; Gevaña et al. 2017; Sharma et al. 2017; Dimalen and Rojo 2019) assessed the carbon stock and carbon dioxide sequestration potential of mangrove ecosystems. The scarcity of information on carbon stock and sequestration capacity of established mangrove stands in the country exists (Castillo and Breva 2012). Knowledge of this aspect of mangrove ecology is vital to climate change mitigation strategies (Murdiyarso et al. 2015) and decision-making processes (Kamruzzaman et al. 2018).

Moreover, no information on biomass, carbon stock, and sequestration capacity of mangroves in Davao Gulf has been published. Among the areas facing Davao Gulf is Panabo City that hosts a 73-hectare Panabo Mangrove Park (City Government of Panabo 2019). Thus, this study assessed the species composition and stand characteristics and estimated the aboveground biomass and carbon stock of mangroves in Panabo Mangrove Park, Panabo City, Davao del Norte, Philippines. The results of this study are expected to provide baseline information on these aspects 
of mangrove ecology in this site. Hence, it can be used as reference for better management of the park and for future studies which aim to investigate the dynamics of mangroves.

\section{MATERIALS AND METHODS}

\section{Study area}

This study was carried out in Panabo Mangrove Park (7¹6’20.579” N, 12540’50.984” E), Panabo City, Davao del Norte. This site was selected as a sampling area due to accessibility and safety considerations (Castillo and Breva 2012; Abino et al. 2014a, b). The mangrove area is managed by the Local Government Unit - Panabo City thru the City Environment and Natural Resources and the Bureau of Fisheries and Aquatic Resources. The area receives tidal inundation regularly and has a muddy soil type with a depth of as much as 1.00 meter. Settlements of approximately more than 100 households within the 500-m radius from the mangrove park were noted. Ongoing construction of a boardwalk and docking area was also observed during the conduct of the study.

\section{Data collection}

In April 2019, fieldwork was done. It utilized the transect line plots method to quantitatively describe species composition, stand structure, and biomass of mangroves (English et al. 1997). Five transects were established perpendicular to the shore. Four $10 \mathrm{~m}$ x $10 \mathrm{~m}$ plots were established to each side of the transect line with a 30-meter distance between them based on stand characteristics. Establishment of replicate plots to the side of the transect line provides an increased likelihood of capturing the variation in mangrove forest stands. To delimit the plots, fiberglass tape, bamboo stakes, and nylon/rope were utilized. A total of 20 plots were established, yielding a total sampled area of $2,000 \mathrm{~m}^{2}$. Inside each plot, a complete inventory of all trees with diameter at breast height (DBH) of at least four centimeters inside the quadrat was done (Canizares and Seronay 2016) following the procedure presented by Howard et al. (2014). For speedy measurement of the $\mathrm{DBH}$ of the individual tree, measuring tape and a marked bamboo pole were used. DBH trees that are fairly straight or leaning were measured parallel to its trunk. For a tree that is forked at or below $130 \mathrm{~cm}, \mathrm{DBH}$ was measured just below the fork, but if the fork is close to the ground, it was considered as two trees. For stilt-rooted Rhizophora species, DBH was measured $130 \mathrm{~cm}$ above the highest stilt root. Mangrove saplings and seedlings were only accounted for biodiversity assessment but not for carbon stock estimation since their DBH are less than four centimeters (Canizares and Seronay 2016).

\section{Identification of species}

All species found in each plot were identified using the Field Guide to the Philippine Mangroves of Primavera (2009). This identification guide was also used in several studies (Barcelete et al. 2016; Pototan et al. 2017). Field Guide to Mangrove Identification and Community Structure Analysis by Lebata-Ramos (2013) was also used. Using both field guides facilitated a better understanding of morphological features of mangroves and easier taxon identification.

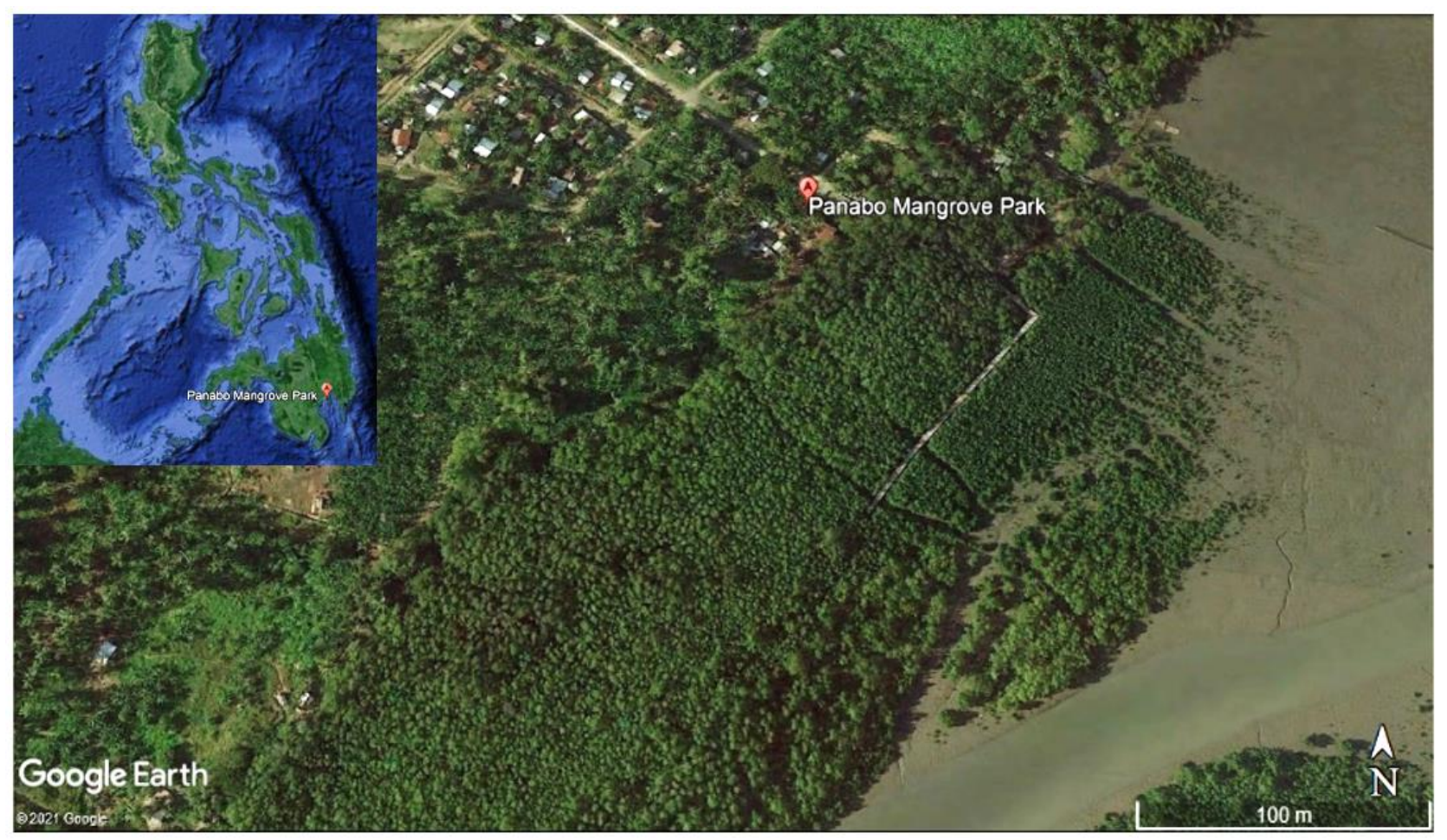

Figure 1. Location of Panabo Mangrove Park, Panabo City, Davao del Norte, Philippines (Google Earth, 2021) 


\section{Data analysis}

Data were analyzed to describe mangrove stand in terms of density (stems ha $\left.{ }^{-1}\right)$, basal area $\left(\mathrm{m}^{2} \mathrm{ha}^{-1}\right)$, relative density, relative frequency, and relative dominance. The importance value of each mangrove species was also determined. They were calculated using the formulas presented by English et al. (1997), and these are as follows.

Basal area per tree $\left(\mathrm{cm}^{2}\right)=\pi \mathrm{DBH}^{2} / 4$

Stand basal area $\left(\mathrm{m}^{2} \mathrm{ha}^{-1}\right)=$ sum of basal areas/area of the plot

Density $\left(\right.$ stems $\left.\mathrm{ha}^{-1}\right)=($ no. of living stems in a plot $\mathrm{x}$ 10,000)/area of the plot

Relative density $=($ density of a species/total density of all species) x 100

Relative frequency $=$ (frequency of a species/total frequency of all species) x 100

Relative density $=$ (total basal area of a species/total basal area of all species) x 100

Importance value $=$ relative density + relative frequency + relative dominance

For diversity analysis, species diversity, richness, and evenness were determined using Shannon-Weiner, Margalef's and Pielou's indices, respectively as presented by Magurran (2004). The formulas are as follows.

Shannon-Weiner Index

$H^{s}=-\Sigma\left[\left(\frac{n i}{N}\right) \ln \left(\frac{n i}{N}\right)\right]$

Where:

$H^{\prime} \quad$ : Shannon-Weiner index

$N \quad$ : total individuals of the population sampled

ln : the natural logarithm

$n_{i} \quad$ : total number of individuals belonging to $i$ species

Margalef's Index

$R=\frac{s-1}{\ln [N]}$

Where:

$R \quad$ : Margalef's index

$S \quad$ : total number of species

$\ln (N)$ : natural logarithm of the total number of individuals

Pielou's Evenness Index

$l=\frac{H s}{H \max }$

Where:

$J \quad$ :Pielou's evenness index

$H^{\prime} \quad$ :Shannon-Weiner index

H'max:diversity observed to a maximum diversity

The aboveground biomass of mangroves was determined using an allometric equation developed by Komiyama et al. (2005). The equation is:

$\mathrm{AGB}=0.251 \mathrm{p} \mathrm{D}^{2.46}$

Where:

AGB : aboveground biomass

$\mathrm{p} \quad$ : wood density

D : diameter at breast height.

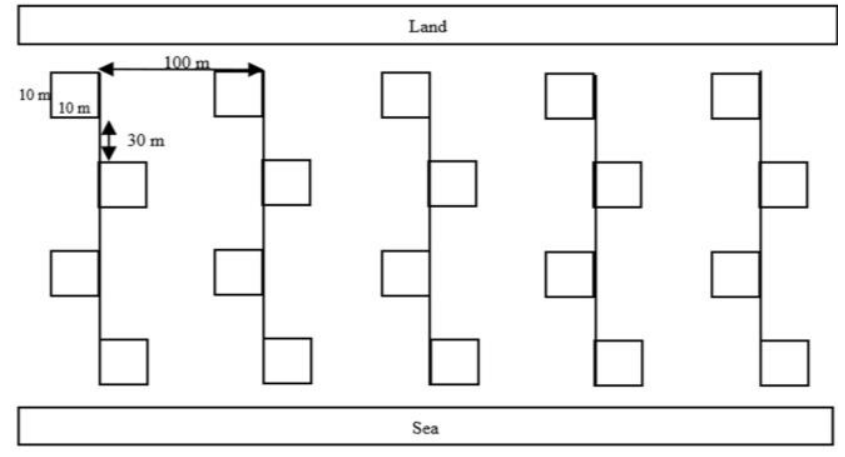

Figure 2. The field survey design using transect line plots method

Species-specific wood density values for common mangroves presented by Howard et al. (2014) were adapted. To estimate carbon stock, the aboveground biomass value is multiplied by a factor of 0.48 (Kauffman and Donato 2012; Howard et al. 2014; Alavaisha and Mangora 2016). Carbon dioxide sequestration potential estimation was done by multiplying the carbon stock value by a factor of 3.67 (Howard et al. 2014).

To determine the relationship between the importance value index and aboveground biomass of mangrove species, Spearman's rank correlation was used. This was calculated using Paleontological Statistics (PAST) software (Hammer et al. 2001).

\section{RESULTS AND DISCUSSION}

\section{Species composition}

A total of 2367 mangrove individuals from all sampling plots were identified in the Panabo Mangrove Park belonging to five different species of the registered 16 species in Panabo City (Pototan et al. 2017). The species identified were Aegiceras corniculatum, Avicennia marina, Rhizophora apiculata, R. mucronata and Sonneratia alba. These species are under four genera of four families as classified by Primavera (2009) and Duke (2011). All identified species in the study site, though with decreasing population trend based on the most recent assessment, are of Least Concern conservation status according to International Union for Conservation of Nature Red List of Threatened Species Version 2021 - 1 (IUCN 2021). None of these species is listed in the National List of Threatened Philippine Plants and their Categories (see DENR Administrative Nos. 2007-01 and 2017-11). The species composition of the study site is summarized in Table 1.

Compared with the different mangrove communities around Davao Gulf, this record of five species showed a lower diversity than Banaybanay, Davao Oriental with 33 species (Pototan et al. 2021), Sta. Cruz, Davao del Sur with 17 species (Cardillo and Novero 2018), Hagonoy, Davao del Sur with 12 species (Jumawan et al. 2015), and Tagum City and Carmen, Davao del Norte with 11 and 12 species, respectively (Pototan et al. 2017). 


\section{Stand characteristics}

Table 2 showed the characteristics of all mangrove species identified in the sampling site. As reflected, $S$. alba, which individual registered the largest DBH of 24.29 $\mathrm{cm}$, accounted for the largest stand basal area $(\mathrm{G})$ of 8.74 $\mathrm{m}^{2} \mathrm{ha}^{-1}$ and the greatest mean DBH of $8.46 \mathrm{~cm}$. In terms of stand basal area, A. marina $\left(8.62 \mathrm{~m}^{2} \mathrm{ha}^{-1}\right)$ came next, then $R$. mucronata $\left(2.02 \mathrm{~m}^{2} \mathrm{ha}^{-1}\right)$ and $R$. apiculata $\left(0.28 \mathrm{~m}^{2}\right.$ $\left.\mathrm{ha}^{-1}\right)$, respectively. However, for mean $\mathrm{DBH}, R$. mucronata $(7.76 \mathrm{~cm})$ ranked second. This was then followed by $A$. marina $(7.22 \mathrm{~cm})$ and $R$. apiculata $(5.90$ $\mathrm{cm})$, respectively. Though A. marina had the highest stem density, its basal area was behind $S$. alba only for its trees have relatively small trunks (Lozano and Bueno 2015), as evidenced in their respective DBH ranges and mean DBH. This result of $S$. alba species with the largest basal area can be attributed to large DBH of the accounted individuals (Cintron and Novelli 1984) even if it did not occur in all plots and not the densest species. Besides, this species has been documented to have a relatively large basal area compared to other species in several mangrove ecosystems in the country, such as Olango Island Wildlife Sanctuary (Lozano and Bueno 2015) and Sarangani Province (Mullet et al. 2014; Natividad et al., 2015). Globally, the basal areas of $S$. alba and A. marina are relatively higher, but the other species' basal areas are lower than the mangroves in Kerala, India (Sreelekshmi et al. 2018). This study recorded no DBH and basal area measurements for $A$. corniculatum since, during fieldwork, all individuals of this species found inside the sampling plots had DBH less than the minimum requirement to be accounted for. Measurement was only limited to those mangrove individuals with $\mathrm{DBH}$, an important component to determine an individual's basal area, of $4.00 \mathrm{~cm}$ or more.

Further, vegetation analysis revealed that $A$. marina, being found in all plots, was the most frequent species with a relative frequency of $28.17 \%$. This occurrence can be attributed to its ability to survive in diverse mangrove habitats and tolerate a wide range of environmental conditions such as salinity and tidal inundation (Tomlinson 1986; Duke 2011). It also registered the highest stem density of 7855 stems $\mathrm{ha}^{-1}$ and a relative density of $66.37 \%$

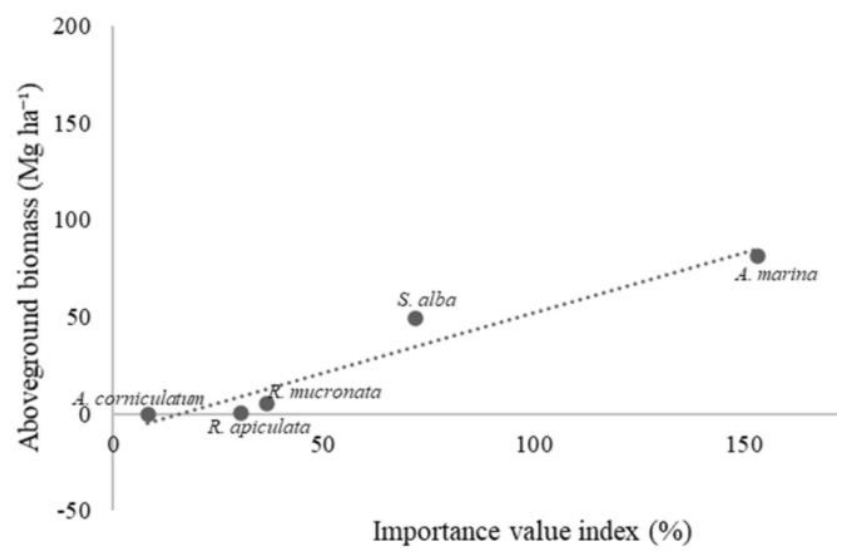

Figure 3. Relationship between important value index and aboveground biomass of mangrove species in Panabo Mangrove Park, Panabo City, Davao del Norte, Philippines

Table 1. Mangrove species identified in Panabo Mangrove Park, Panabo City, Davao del Norte, Philippines

\begin{tabular}{llcr}
\hline Species & Family & Conservation Status & $\begin{array}{r}\text { Total number of } \\
\text { sampled individuals }\end{array}$ \\
\hline Aegiceras corniculatum (L.) Blanco & Myrsinaceae & Least Concern & 27 \\
Avicennia marina (Forsk.) Vierh & Avicenniaceae & Least Concern & 1571 \\
Rhizophora apiculata Blume & Rhizophoraceae & Least Concern & 143 \\
Rhizophora mucronata Lamk & Rhizophoraceae & Least Concern & 296 \\
Sonneratia alba J. Smith & Sonneratiaceae & Least Concern & 330 \\
Total & & & 2367 \\
\hline
\end{tabular}

Table 2. Characteristics of different mangrove species in Panabo Mangrove Park, Panabo City, Davao del Norte, Philippines

\begin{tabular}{|c|c|c|c|c|c|c|c|c|c|}
\hline Rank & Species & $\begin{array}{l}\text { DBH Range } \\
\quad(\mathrm{cm})\end{array}$ & $\begin{array}{l}\text { Mean DBH } \\
\quad(\mathrm{cm})\end{array}$ & $\begin{array}{c}\text { Stand basal } \\
\text { area } \\
\left(\mathbf{m}^{2} \mathbf{h a}^{-1}\right) \\
\end{array}$ & $\begin{array}{c}\text { Mean } \\
\text { density } \\
\left.\text { (stems ha }{ }^{-1}\right)\end{array}$ & $\begin{array}{c}\text { Relative } \\
\text { frequency } \\
(\%)\end{array}$ & $\begin{array}{c}\text { Relative } \\
\text { density } \\
(\%)\end{array}$ & $\begin{array}{c}\text { Relative } \\
\text { dominance } \\
(\%)\end{array}$ & $\begin{array}{c}\text { Importance } \\
\text { Value } \\
(\%)\end{array}$ \\
\hline 1 & Avicennia marina & $4.77-18.46$ & $7.22 \pm 0.13$ & $8.62 \pm 1.62$ & $7855 \pm 925$ & 28.17 & 66.37 & 58.79 & 153.33 \\
\hline 2 & Sonneratia alba & $4.84-24.29$ & $8.46 \pm 0.30$ & $8.74 \pm 1.16$ & $1650 \pm 444$ & 19.72 & 13.94 & 38.17 & 71.83 \\
\hline 3 & Rhizophora mисronata & $5.09-12.06$ & $7.76 \pm 0.52$ & $2.02 \pm 0.90$ & $1480 \pm 1126$ & 21.13 & 12.51 & 2.76 & 36.40 \\
\hline 4 & Rhizophora apiculata & $5.03-7.58$ & $5.90 \pm 0.84$ & $0.28 \pm 0.08$ & $715 \pm 141$ & 23.94 & 6.04 & 0.29 & 30.27 \\
\hline 5 & Aegiceras corniculatum & - & - & - & $135 \pm 79$ & 7.04 & 1.14 & 0.00 & 8.18 \\
\hline
\end{tabular}

Note: Data on mean DBH, stand basal area, and mean density are presented in mean \pm standard error. The mark - means no data available during study period since the identified individuals had DBH of less than $4.00 \mathrm{~cm}$ 
Furthermore, it was found to be dominating the area with a relative dominance of $58.79 \%$. Even if it did not post the highest mean basal area among all species, it was still the most dominant due to its considerably high density (Kauffman and Bhomia 2017). With these, A. marina was the most important species with an importance value index (IVI) of $153.33 \%$. Moreover, S. alba ranked second with an importance value of $71.83 \%$, followed by $R$. mucronata with $36.40 \%$, then $R$. apiculata with $30.27 \%$. A corniculatum is considered to be the least important species with an importance value of $8.18 \%$. This account implies that $A$. marina is the most acclimatized (Pototan et al. 2017) and has the greatest biomass contribution (Pototan et al. 2021) in the area. Further, this study revealed a positive correlation between the IVI and aboveground biomass of mangrove species (Figure 3) which means that species with higher IVI have greater aboveground biomass accumulation. Truly, the most important species, A. marina, had the most contribution to the stand aboveground biomass with 81.57 $\mathrm{Mg} \mathrm{ha}^{-1}$ (see Table 5). This finding affirmed the result of Matatula et al. (2021) which reported that a significant correlation exists between species importance value index and aboveground biomass.

Table 3 showed the stand characteristics of Panabo Mangrove Park. Structural analysis recorded a mean DBH of $7.67 \mathrm{~cm}$, a stand basal area of $14.65 \mathrm{~m}^{2} \mathrm{ha}^{-1}$, and a mean density of 11835 stems $\mathrm{ha}^{-1}$. Compared with other mangrove communities in the Philippines, its mean DBH measurement is relatively higher than those measurements in Calatagan Mangrove Forest Conservation Park, Batangas (Cudiamat and Rodriguez 2017), several plantations stand in Banacon Island, Bohol (Camacho et al. 2011; Gevaña et al. 2017) and afforested mangrove stands in Laguindingan, Misamis Oriental (Sharma et al. 2017). However, it is lower than those in San Juan, Batangas (Gevaña et al. 2008), Bahile Village, Palawan (Abino et al. 2014b), and Pinabacdao, Samar (Abino et al. 2014a). Also, its stand basal area is relatively higher than the basal areas of 3- and 9-year-old afforested stands in Laguindingan, Misamis Oriental (Sharma et al. 2017), Olango Island Wildlife Sanctuary, Cebu (Lozano and Bueno 2015), and Calatagan Mangrove Forest Conservation Park, Batangas (Cudiamat and Rodriguez 2017). However, it is lower than the 21-year-old mangrove stands in Laguindingan, Misamis Oriental (Sharma et al. 2017) and surveyed zones along Puerto Princesa Bay, Palawan (Dangan-Galon et al. 2016). Furthermore, its mean stem density is relatively lower than the young stands in Banacon Island, Bohol (Gevaña et al. 2017) but higher than the inventories reported by DanganGalon et al. (2016) in Puerto Princesa Bay, Palawan, Lozano and Bueno (2015) in Olango Island Wildlife Sanctuary, Cebu, and Sharma et al. (2017) in afforested mangrove stands in Laguindingan, Misamis Oriental.

\section{Diversity analysis}

As shown in Table 4, the study site had low species diversity $\left(H^{\prime}=1.0273\right)$. This could be due to harsh environmental conditions that threaten the growth and development of varied mangrove species in coastal habitats (Duke 2011). Another possible reason for the low diversity level is the planting of pre-selected species during reforestation (Picardal et al. 2011). Newly planted Rhizophora species in the area were observed during fieldwork. On the other hand, a less even distribution of species $(J=0.6383)$ was also noted. This result is primarily due to the abundance of $A$. marina that dominates the site. In terms of species richness, the area registered an overall index value of 0.5148 , which is deemed to be low given that there were only five species identified in all sampling plots.

\section{Aboveground biomass and carbon stock estimation}

Biomass measurement is a prerequisite for carbon stock estimation so is the latter for the calculation of carbon dioxide sequestration potential (Intergovernmental Panel on Climate Change 2013; Howard et al. 2014). As shown in Table 5, the mean aboveground living biomass (AGB) of mangroves in Panabo Mangrove Park was $77.45 \mathrm{Mg} \mathrm{ha}^{-1}$, equivalent to an aboveground living carbon (AGC) stock of $37.18 \mathrm{Mg} \mathrm{ha}^{-1}$. This record means that the study site can sequester at least $136.44 \mathrm{Mg} \mathrm{CO} \mathrm{ha}^{-1}$. Notably, the accounted aboveground living biomass of the study site can only be attributed to four species, namely (in order of contribution): A. marina, $S$. alba, $R$. mucronata, and $R$. apiculata. Of the four species, the $A$. marina, being the most important species, had the greatest contribution due to its highest stem density (Abino et al. 2014b). This species was also documented in Catmon, San Juan, Batangas, the Philippines as the greatest contributor to stand aboveground biomass and stored carbon (Gevaña et al. 2008).

Table 3. Characteristics of mangrove stand in Panabo Mangrove Park, Panabo City, Davao del Norte, Philippines

\begin{tabular}{lll}
\hline Stand characteristics & Unit & Mean value \\
\hline Diameter at breast height & $\mathrm{cm}$ & 7.67 \\
Stand basal area & $\mathrm{m}^{2} \mathrm{ha}^{-1}$ & 14.65 \\
Density & trees ha' & 11835 \\
\hline
\end{tabular}

Table 4. Biodiversity indices of mangrove stand in Panabo Mangrove Park, Panabo City, Davao del Norte, Philippines

\begin{tabular}{lc}
\hline Biodiversity indices & Value \\
\hline Shannon-Weiner Index & 1.0273 \\
Pielou's Index & 0.6383 \\
Margalef's Index & 0.5148 \\
\hline
\end{tabular}

Table 5. Estimated aboveground living biomass, carbon stock, and carbon dioxide sequestration potential of mangroves in Panabo Mangrove Park, Panabo City, Davao del Norte, Philippines

\begin{tabular}{lccr}
\hline Species & $\begin{array}{c}\text { Aboveground } \\
\text { living biomass } \\
\left(\mathbf{m g ~ h a}^{-1}\right)\end{array}$ & $\begin{array}{c}\text { Carbon } \\
\text { stock } \\
\left(\mathbf{m g ~ h a}^{-1}\right)\end{array}$ & $\begin{array}{r}\mathbf{C O}_{2} \text { sequestr. } \\
\text { potential } \\
\left(\mathbf{m g ~ h a}^{-1}\right)\end{array}$ \\
\hline Avicennia marina & 46.30 & 22.23 & 81.57 \\
Sonneratia alba & 27.98 & 13.43 & 49.29 \\
Rhizophora mucronata & 2.89 & 1.39 & 5.10 \\
Rhizophora apiculata & 0.28 & 0.13 & 0.49 \\
Total & 77.45 & 37.18 & 136.44 \\
\hline
\end{tabular}


IPCC (2013) provided a range of default values for aboveground biomass of mangroves in tropical wet areas. The range is 8.7 to $384 \mathrm{Mg} \mathrm{ha}^{-1}$. Also, Howard et al. (2014) presented that carbon stock is estimated to be 55 to 1376 $\mathrm{Mg} \mathrm{ha}{ }^{-1}$ with an average of $386 \mathrm{Mg} \mathrm{ha}^{-1}$ and an average carbon dioxide equivalent of $1415 \mathrm{Mg} \mathrm{ha}^{-1}$. With this, it can be noted that the estimated biomass of the study site was within the range of default values. However, carbon stock and carbon dioxide equivalent were lower than the estimated averages for this study considered only the aboveground living component of the mangroves. Also, given that about $21 \%$ of stored carbon in the mangrove ecosystem can be attributed to aboveground living biomass (Howard et al. 2014), the area can store as much as 177.05 $\mathrm{Mg} \mathrm{C} \mathrm{ha-1}$. In addition, the sampled area can potentially sequester as much as $649.77 \mathrm{Mg} \mathrm{CO}_{2} \mathrm{ha}^{-1}$.

To date, limited studies are available on biomass, carbon stock, and carbon dioxide sequestration potential of mangroves in the Philippines. The mean values generated in this study were relatively higher than those of Rhizophora stand in Verde Passage, San Juan, Batangas (Gevaña and Pampolina 2009), Rhizophora-dominated large plot in Poctol, San Juan, Batangas (Gevaña et al. 2008), Avicennia-dominated small plots in Catmon, San Juan, Batangas (Gevaña et al. 2008) and 3- and 9-year-old afforested stands in Laguindingan, Misamis Oriental (Sharma et al. 2017). Also, this account was even higher than that of a 22-year-old reforested stand in Aklan (Castillo and Breva 2012). On the other hand, it can be noted that these values were relatively lower than those of Sarangani Province (Barcelete et al. 2016; Bigsang et al. 2016), Cotabato City (Dimalen and Rojo 2019), 21 year-old afforested stand in Laguindingan, Misamis Oriental (Sharma et al. 2017), plantation and natural stands in Banacon Island, Bohol (Camacho et al. 2011; Gevaña et al. 2017), natural and reforested stands in Samar (Castillo and Breva 2012; Abino et al. 2014a) and natural and reforested stands in Palawan (Castillo and Breva 2012; Abino et al. 2014; Venturillo 2016).

Globally, the estimated biomass and stored carbon of Panabo Mangrove Park were relatively higher than those of the oligohaline zone of Dhangmari area, Sundarbans, Bangladesh (Kamruzzaman et al. 2018), A. marinadominated zone along Yinglou Bay, South China (Wang et al. 2014), Pulau Semakau, Singapore (Friess et al. 2016), open-canopy mangroves in Mahajamba Bay, Madagascar (Jones et al. 2015), Piraque-Acu River, Brazil (da Motta Portillo et al. 2017), restored mangrove sites in Muisne, Esmeraldas Province, Ecuador (DelVecchia et al. 2014) and the Pacific Coast and Bay Islands in Honduras (Bhomia et al. 2016). However, these estimates were not as high as those in neighboring Asian countries such as Vietnam (Nam et al. 2016), Malaysia (Hossain 2014; Ismail et al. 2015; Suhaili et al. 2020), Indonesia (Murdiyarso et al. 2015; Alongi et al. 2016; Asadi et al. 2018; Widyastuti et al. 2018), India (Kathiresan et al. 2013; Hebbalalu et al. 2014; Sahu et al. 2016) and H. fomesdominated vegetation in Sundarbans, Bangladesh (Rahman et al. 2015). Further, this account was even lower than the records in East Coast, Florida (Doughty et al. 2016) and several African countries such as Liberia (Tang et al. 2016; Kauffman and Bhomia 2017), Mozambique (Sitoe et al. 2014; Trettin et al. 2016), Tanzania (Alavaisha and Mangora 2016), Cameroon (Tang et al. 2016) and Gabon (Kauffman and Bhomia 2017).

Differences in measurements of biomass, carbon stock, and carbon dioxide sequestration potential among areas around the globe can be due to different environmental factors (e.g., temperature, precipitation, tidal inundation, river flows, nutrient cycling and availability, salinity) and even morphological characteristics (e.g., size) that affect productivity and rate of respiration of mangrove ecosystems (Alongi 2012). Several studies (Jones et al. 2015; Alavaisha and Mangora 2016; Kauffman and Bhomia 2017) have also attributed these differences to environmental variability.

In conclusion, even if the site has very low species diversity, low species richness, and less even distribution of species, its ability to store and sequester carbon and carbon dioxide, respectively, cannot be undermined. Thus, conservation and protection efforts should be continued, especially that the area has become a local ecotourism destination. Periodic monitoring of this aspect of mangrove ecology and estimation of carbon in other pools are recommended as this information is equally helpful in mangrove conservation and management.

\section{ACKNOWLEDGEMENTS}

We are grateful to the Graduate School of Davao del Norte State College and the local government of Panabo City, Philippines for their support in the conduct of this study and to the University of Mindanao and the UM Tagum College, in particular, for the assistance in the publication of this paper. Special thanks to Dr. JH Primavera, Dr. MJH Lebata-Ramos, Dr. JP Altamirano, and Forester BL Pototan for their assistance in verifying the species. Efforts of the group, led by Karyn Chrislene A. Vitor, who helped during data collection, are much appreciated. The authors declare no conflicts of interest regarding the publication of this paper.

\section{REFERENCES}

Abino AC, Castillo JAA, Lee YJ. 2014a. Assessment of species diversity, biomass and carbon sequestration potential of a natural mangrove stand in Samar, the Philippines. For Sci Technol 10: 2-8. DOI: 10.1080/21580103.2013.814593.

Abino AC, Castillo JAA, Lee YJ. 2014b. Species diversity, biomass, and carbon stock assessments of a natural mangrove forest in Palawan, Philippines. Pak J Bot 46: 1955-1962.

Alavaisha E, Mangora MM. 2016. Carbon stocks in the small estuarine mangroves of Geza and Mtibwani, Tanga, Tanzania. Intl J For Res 2016: 1-11. DOI: 10.1155/2016/2068283.

Alongi DM, Murdiyarso D, Fourqurean JW, Kauffman JB, Hutahaean A, Crooks S, Lovelock CE, Howard J, Herr D, Fortes M, Pidgeon E, Wagey T. 2016. Indonesia's blue carbon: a globally significant and vulnerable sink for seagrass and mangrove carbon. Wetl Ecol Manag, 24: 3-13. DOI: 10.1007/s11273-015-9446-y.

Alongi DM. 2012. Carbon sequestration in mangrove forests. Carbon Manag 3: 313-322. DOI: 10.4155/CMT.12.20. 
Alongi DM. 2014. Carbon cycling and storage in mangrove forests. Annu Rev Mar Sci 6: 195-219. DOI: 10.1146/annurev-marine-010213135020.

Asadi MA, Yona D, Saputro SE. 2018. Species diversity, biomass and carbon stock assessments of mangrove forest in Labuhan, Indonesia IOP Conf. Series: Earth Environ Sci 151: 012009. DOI :10.1088/1755-1315/151/1/012009.

Barcelete RC, Palmero EMF, Buay BMG, Apares CB, Dominoto LR, Lipae H, Cabrera MLN, Torres MAJ, Requiron EA. 2016. Species diversity and above-ground carbon stock assessments in selected mangrove forests of Malapatan and Glan, Sarangani Province, Philippines. J Biodivers Environ Sci 8: 265-274.

Bhomia RK, Kauffman JB, McFadden TN. 2016. Ecosystem carbon stocks of mangrove forests along the Pacific and Caribbean coasts of Honduras. Wetl Ecol Manag 24: 187-201. DOI:10.1007/s11273-0169438-1.

Bigsang RT, Agonia NB, Toreta CGD, Nacin CJCB, Obemio CDG, Martin TTB. 2016. Community structure and carbon sequestration potential of mangroves in Maasim, Sarangani Province, Philippines. AES Bioflux 8: 6-13.

Breva LA. 2006. Carbon stock assessment of a mangrove forest in Padre Burgos, Quezon, Philippines.

Buitre MJC, Zhang H, Lin H. 2019. The mangrove forests change and impacts from tropical cyclones in the Philippines using time-series satellite imagery. Remote Sens 1: 688. DOI:10.3390/RS11060688

Camacho LD, Gevaňa DT, Carandang AP, Camacho SC, Combalicer EA, Rebugio LL, Youn Y-C. 2011. Tree biomass and carbon stock of a community-managed mangrove forest in Bohol, Philippines. For Sci Technol 7: 161-167. DOI: 10.1080/21580103.2011.621377.

Camacho LD, Gevaña DT, Sabino LL, Ruzol CD, Garcia JE, Camacho ACD, Oo TN, Maung AC, Saxena KG, Liang L, Yiu E, Takeuchi K. 2020. Sustainable mangrove rehabilitation: Lessons and insights from community-based management in the Philippines and Myanmar. APN Sci Bull 10:18-25. DOI: 10.30852/sb.2020.983.

Caňizares LP, Seronay RA. 2016. Diversity and species composition of mangroves in Barangay Imelda, Dinagat Island, Philippines. AACL Bioflux 9: 518-526.

Cardillo J, Novero AU. 2018. Assessment of mangrove diversity in Santa Cruz, Davao del Sur, Philippines. J Biodivers Environ Sci 14: 53-62.

Castillo JAA, Breva LA. 2012. Carbon stock assessment of four mangrove reforestations/plantation stands in the Philippines. Proceedings of the 1st ASEAN Congress on Mangrove Research and Development. 3-7 December 2012. [Philippines]

Cintron G, Novelli YS. 1984. Methods for studying mangrove structure. In: Snedaker SC, Snedaker JG (eds). The Mangrove Ecosystem: Research Methods. Bungay, United Kingdom.

City Government of Panabo City. 2019. Panabo mangrove park ecotourism project inaugurated. www.panabocity.gov.ph

Cudiamat MA, Rodriguez RA. 2017. Abundance, structure and diversity of mangroves in a community-managed forest in Calatagan, Batangas, Verde Island Passage, Philippines. Asia Pac J Multidiscip Res 5: 27 33.

da Motta Portillo JT, Londe V, Moreira FWA. 2017. Aboveground biomass and carbon stock are related with soil humidity in a mangrove at the Piraque-Acu River, Southeastern Brazil. J Coast Conserv 21: 139-144. DOI: 10.1007/s11852-016-0482-4.

Dangan-Galon F, Dolorosa RG, Sespene JS, Mendoza NI. 2016. Diversity and structural complexity of mangrove forest along Puerto Princesa Bay, Palawan Island, Philippines. J Mar Isl Cult 5: 118-125. DOI: 10.1016/j.imic.2016.09.001

DelVecchia AG, Bruno JF, Benninger L, Alperin M, Banerjee O, de Dios Morales J. 2014. Organic carbon inventories in natural and restored Ecuadorian mangrove forests. PeerJ 2 e388. DOI: 10.7717/peerj.388.

Department of Environment and Natural Resources Administrative Order No. 2007-01. 2007. Establishing the national list of threatened Philippine plants and their categories, and the list of other wildlife species.

Department of Environment and Natural Resources Administrative Order No. 2017-11. 2017. Updated national list of threatened Philippine plants and their categories.

Dimalen FK, Rojo MJA. 2019. Carbon stock assessment of a mangrove forest in Cotabato City, Philippines. J Biodivers Environ Sci 14: 1-8.

Dinilhuda A, Akbar AA, Jumiati, Herawati H.2020. Potential of mangrove ecosystem as carbon storage for global warming mitigation. Biodiversitas 21:5353-5362. DOI: 10.13057/biodiv/d211141.
Doughty CL, Langley JA, Walker WS, Feller IC, Schaub R, Chapman SK 2016. Mangrove range explosion rapidly increases coastal wetland carbon storage. Estuar Coasts 39: 385-396. DOI: 10.1007/s12237015-9993-8

Duke NC. 2011. Mangroves. Encyclopedia of Earth Sciences Series. DOI: 10.1007/978-90-481-2639-2 108

English S, Wilkinson C, Baker V. 1997. Survey Manual for Tropical Marine Resources. 2nd ed.. Australian Institute of Marine Science, Townsville, Australia

Food and Agricultural Organization of the United Nations. 2007. The world's mangroves 1980 - 2005. Rome, Italy.

Friess DA, Richards DR, Phang VX. 2016. Mangrove forests store high densities of carbon across the tropical urban landscape of Singapore. Urban Ecosyst 19: 795-810. DOI: 10.1007/s11252-015-0511-3.

Garcia KB, Malabrigo PL, Gevaña DT. 2014. Philippines' mangrove ecosystem: status, threats and conservation. In: Faridah-Hanum I, Latiff A, Hakeem KR, Ozturk M (eds) Mangrove Ecosystems of Asia. Springer, New York.

Gevaña DT, Camacho LD, Camacho SC. 2017. Stand density management and blue carbon stock of monospecific mangrove plantation in Bohol, Philippines. For Stud 66:75-83. DOI: 10.1515/fmsu-2017-0008.

Gevaňa DT, Pampolina NM. 2009. Plant diversity and carbon storage of a Rhizophora stand in Verde Passage, San Juan, Batangas, Philippines. J Environ Sci Manag 12: 1-10.

Gevaňa DT, Pulhin FB, Pampolina NM. 2008. Carbon stock assessment of a mangrove ecosystem in San Juan, Batangas. J Environ Sci Manag 11: $15-25$.

Gevaña DT, Pulhin JM, Tapia MA. 2019. Fostering climate change mitigation through a community-based approach: Carbon stock potential of community-managed mangroves in the Philippines. In: Krishnamurthy RR, Jonathan MP, Srinivasalu S, Glaeser B (eds.) Coastal Management. Academic Press, New York. DOI: 10.1016/B978-0-12-810473-6.00014-5

Hammer $\varnothing$, Harper DAT, Ryan PD. 2001. PAST: Paleontological statistics software package for education and data analysis. Palaeontol Electron 4: 1-9.

Hebbalalu SS, Bhat DM, Nijavalli RH, Raman S. 2014. Diversity, structure and dynamics of a mangrove forest: a case study. Not Sci Biol 6: 300-307. DOI: 10.15835/nsb.6.3.9339.

Hossain M. 2014. Carbon pools and fluxes in Briguiera parviflora dominated naturally growing mangrove forest of Peninsular Malaysia. Wetl Ecol Manag 22: 15-23. DOI: 10.1007/s11273-013-9318-2.

Howard J, Hoyt S, Isensee K, Pidgeon E, Telszewski M. 2014. Coastal blue carbon: methods of assessing carbon stocks and emission factors in mangroves, tidal salt marshes, and seagrass meadows. Conservation International, Intergovernmental Oceanographic Commission of UNESCO. International Union for Conservation of Nature, Arlington, VA, USA.

Intergovernmental Panel on Climate Change. 2013. Supplement to the 2006 IPCC guidelines for national greenhouse gas inventories: Wetlands. IPCC, Switzerland.

International Union for the Conservation of Nature. 2021. The IUCN Red List of Threatened Species. Version 2021-1. www.iucnredlist.org

Ismail MH, Zaki PH, Hamed AA. 2015. Wood density and carbon estimates of mangrove species in Kuala Sepetang, Perak, Malaysia. Malays For 78: 115-124.

Jones TG, Ratsimba HR, Ravaoarinorotsihoarana L, Glass L, Benson L, Teoh M, Carro A, Cripps G, Giri C, Gandhi S, Andriamahenina Z, Rakotomanana R, Roy PF. 2015. The dynamics, ecological variability and estimated carbon stocks of mangroves in Mahajamba Bay, Madagascar. J Mar Sci Eng 3: 793-820. DOI: 10.3390/jmse3030793

Jumawan J, Flores FL, Aragon RT, Villamor JMC, Sagot JC, Taguse, HC, Genecera J, Banas GG, Depamaylo AMV. 2015. Diversity assessment and spatial structure of mangrove community in a rehabilitated landscape in Hagonoy, Davao del Sur, Philippines. AES Bioflux 7: 475-482.

Kamruzzaman M, Ahmed S, Paul S, Rahman MM, Osawa A. 2018. Stand structure and carbon storage in the oligohaline zone of Sundarbans mangrove forest, Bangladesh. For Sci Technol 14: 23-28. DOI: 10.1080/215801030.2017.1417920.

Kathiresan K, Anburaj R, Gomathi V, Saravanakumar K. 2013. Carbon sequestration potential of Rhizophora mucronata and Avicennia marina as influenced by age, season, growth and sediment characteristics in southeast coast of India. J Coast Conserv 17: 397 408. DOI: $10.1007 / \mathrm{s} 11852-013-0236-5$. 
Kauffman JB, Bhomia RK. 2017. Ecosystem carbon stocks of mangroves across broad environmental gradients in West-Central Africa: globa and regional comparisons. PLoS ONE 12: 1-17. DOI 10.1371/journal.pone.0187749.

Kauffman JB, Donato DC. 2012. Protocols for the measurement, monitoring and reporting of structure, biomass and carbon stocks in mangrove forest. Working Paper, Center for International Forestry Research, Bogor.

Komiyama A, Poungparn S, Kato S. 2005. Common allometric equations for estimating the tree weight of mangroves. J Trop Ecol 21: 471-477. DOI: $10.1017 / \mathrm{S} 0266467405002476$.

Lebata-Ramos M. 2013. Field guide to mangrove identification and community structure analysis. SEAFDEC Aquaculture Department, Iloilo, Philippines

Lozano EB, Bueno RG. 2015. Species composition, diversity and stand structure of mangroves in Olango Island Wildlife Sanctuary, Cebu, Philippines. CNU J High Educ 9: 28-38.

Magurran AE. 2004. Measuring Biological Diversity. Blackwell, Oxford.

Matatula J, Afandi AY, Wirabuana PYAP. 2021. Short communication: A comparison of stand structure, species diversity and aboveground biomass between natural and planted mangroves in Sikka, East Nusa Tenggara, Indonesia. Biodiversitas 22: 1098-1103. DOI: 10.13057/biodiv/d220303.

Melana DM, Melana EE, Mapalo AM. 2005. Mangroves management and development in the Philippines. Aquaculture Department, Southeas Asian Fisheries Development Center, Philippines.

Mullet EKC, Lacorte GH, Hamiladan RMA, Arabit CEM, Cuales SO, Lasutan LGC, Alagos NJS, Kamantu HG, Protacio KJT, Jumawan JH. 2014. Assessment of mangrove species and its relation to soil substrates in malapatan, Sarangani Province, Philippines. J Biodivers Environ Sci 5: 100-107.

Murdiyarso D, Purbopuspito J, Kauffman JB, Warren MW, Sasmito SD, Donato DC, Manuri S, Krisnawati H, Taberima S, Kurnianto S. 2015 The potential of Indonesian mangrove forests for global climate change mitigation. Nat Clim Change 5: 1089-1092. DOI: 10.1038/NCLIMATE2734.

Nam VN, Sasmito SD, Murdiyarso D, Purbopuspito J, MacKenzie RA 2016. Carbon stocks in artificially and naturally regenerated mangrove ecosystems in the Mekong Delta. Wetl Ecol Manag 24: 231-244. DOI: 10.1007/s11273-015-9479-2.

Natividad EMC, Hingabay VS, Lipae HB, Requieron EA, Abalunan AJ, Tagaloguin PM, Flamiano RS, Jumawan JH, Jumawan JC. 2015 Vegetation analysis and community structure of mangroves in Alabel and Maasim, Sarangani Province Philippines. ARPN J Agric Biol Sci 10: 97-102.

Picardal JP, Avila STR, Tano MF, Marababol MS. 2011. The species composition and associated fauna of the mangrove forest in Tabuk and Cabgan Islets, Palompon Leyte, Philippines. CNU J High Educ 5: $1-18$

Pototan BL, Capin NC, Delima AGD, Novero AU. 2021. Assessment of mangrove species diversity in Banaybanay, Davao Oriental, Philippines. Biodiversitas 22: 144-153. DOI: 10.13057/biodiv/d220120.

Pototan BL, Capin NC, Tinoy MRM, Novero AU. 2017. Diversity of mangrove species in three municipalities of Davao del Norte, Philippines. AACL Bioflux 10: 1569-1579.

Primavera JH. 2004. Philippine mangroves: status, threats, and sustainable development. In: Vannucci M (ed) Mangrove management and conservation: present and future. United Nations University Press, Tokyo.
Primavera JH. 2009. Field guide to the Philippine mangroves. Philippine Tropical Forest Conservation Foundation, Inc. and Zoological Society of London, UK.

Rahman MM, Khan MNI, Hoque AF, Ahmed I. 2015. Carbon stock in the Sundarbans mangrove forest: spatial variations in vegetation types and salinity zones. Wetl Ecol Manag 23: 269-283. DOI: 10.1007/s11273-014-9379-x.

Sahu SC, Kumar M, Ravindranath NH. 2016. Carbon stocks in natural and planted mangrove forests of Mahandi Mangrove Wetland, East Coast of India. Curr Sci 110: 2334-2341. DOI: $10.18520 / \mathrm{cs} / \mathrm{v} 110 / \mathrm{i} 12 / 2334-$ 2341.

Satyanarayana B, Bhanderi P, Debry M, Maniatis D, Foré F, Badgie D, Jammeh K, Vanwing T, Farcy C, Koedam N, Dahdouh-Guebas, F. 2012. A socio-ecological assessment aiming at improved forest resource management and sustainable ecotourism development in the mangroves of Tanbi Wetland National Park, The Gambia, West Africa. Ambio 41: 513-526. DOI: 10.1007/s13280-012-0248-7.

Sawairnathan MI, Halimoon N. 2017. Assessment of the local communities' knowledge on mangrove ecology. Intl J Hum Capital Urban Manage 2: 125-138. DOI: 10.22034/ijhcum.2017.02.02.004

Sharma S, Nadaoka K, Nakaoka M, Uy WH, MacKenzie RA, Friess DA, Fortes MD. 2017. Growth performance and structure of a mangrove afforestation project on a former seagrass bed, Mindanao Island, Philippines. Hydrobiol 803: 359-371. DOI: 10.1007/s10750-0173252-X.

Sitoe AA, Mandlate LJC, Guedes BS. 2014. Biomass and carbon stocks of Sofala Bay mangrove forests. Forestry 5: 1967-1981. DOI: 10.3390/f5081967.

Spalding M, Kainuma M, Collins L. 2010. World Atlas of Mangroves. Earthscan, London.

Sreelekshmi S, Preethy CM, Varghese R, Joseph P, Asha CV, Nandan SB, Radhakrishnan CK. 2018. Diversity, stand structure, and zonation pattern of mangroves in southwest coast of India. J Asia-Pac Biodivers 11: 573-582. DOI: 10.1016/japb.2018.08.001.

Suhaili NS, Fei JLJ, Sha'ari FW, Idris MI, Hatta SH, Kodoh J, Besar NA. 2020. Carbon stock estimation of Sulaman Lake Forest Reserve in Sabah, Malaysia. Biodiversitas 21:5657-5664. DOI: 10.13057/biodiv/d211223.

Tang W, Feng W, Jia M, Shi J, Zuo H, Trettin CC. 2016. The assessment of mangrove biomass and carbon in West Africa: a spatially explicit analytical framework. Wetl Ecol Manag 24: 153-171. DOI:10.1007/s11273-015-9474-7.

Tomlinson PB. 1986. The Botany of Mangroves. Cambridge University Press, London.

Trettin CC, Stringer CE, Zarnoch SJ. 2016. Composition, biomass and structure of mangroves within the Zambezi River Delta. Wetl Ecol Manag 24: 173-186. DOI:10.1007/s11273-015-9465-8.

Venturillo RM. 2016. Spatio-temporal mapping, biomass and carbon stock assessment of mangrove forest in Aborlan, Palawan, Philippines. J Nat Stud 15: 90-103.

Wagner GM, Akwilapo FD, Mrosso S, Ulomi S, Masinde R. 2004. Assessment of marine biodiversity, ecosystem health, and resource status in mangrove forests in Mnazi Bay Ruvuma Estuary Marine Park. IUCN, UNDP, MPRU, GEF, Nairobi, Kenya.

Wang G, Guan D, Zhang Q, Peart MR, Chen Y, Peng Y, Ling X. 2014. Spatial patterns of biomass and soil attribute in an estuarine mangrove forest (Yingluo Bay, South China). Eur J Forest Res 133: 993-1005. DOI: $10.1007 / \mathrm{s} 10342-014-0817-3$.

Widyastuti A, Yani E, Nasultion EK, Rochmatino. 2018. Diversity of mangrove vegetation and carbon sink estimation of Segara Anakan mangrove Forest, Cilacap, Central Java, Indonesia. Biodiversitas 19: 246-252. DOI: 10.13057/biodiv/d190133. 